\title{
Ectopic Tissue
}

National Cancer Institute

\section{Source}

National Cancer Institute. Ectopic Tissue. NCI Thesaurus. Code C132486.

A tissue that forms in a location of the body at or in which it is not normally associated. 